\title{
Tailored $\mathrm{ZnS} / \mathrm{Ag} / \mathrm{TiO}_{\mathrm{x}}$ transparent and conductive electrode for organic solar cells
}

\author{
Mohamed Ahmed Cherif ${ }^{1,3}$, Amina Labiod ${ }^{1}$, Damien Barakel ${ }^{1}$, Saad Touihri ${ }^{2}$, and Philippe Torchio ${ }^{1, *}$ \\ 1 Aix-Marseille Université, Institut Matériaux Microélectronique Nanosciences de Provence-IM2NP, CNRS-UMR 7334, \\ Domaine Universitaire de Saint-Jérôme, 13397 Marseille Cedex 20, France \\ 2 UPDS, Faculté des Sciences de Tunis, Université de Tunis El Manar, Tunis, Tunisia \\ 3 École Nationale d'Ingénieurs de Tunis ENSIT, Université de Tunis, Tunis, Tunisia
}

Received: 14 January 2019 / Received in final form: 26 April 2019 / Accepted: 6 May 2019

\begin{abstract}
Organic photovoltaic cells (OPVCs) attract high interest for solar energy harvesting. They are based on organic thin films sandwiched between two electrodes, one of them being transparent and conductive. Nowadays, ITO remains the most widely used transparent conductive electrode (TCE) because of its excellent optical and electrical properties compared to other TCEs. However, it has some drawbacks such as scarcity of indium, high fabrication cost, and mechanical properties poorly adapted to use as flexible substrates. To keep these performances without indium, several materials can replace ITO such as $\mathrm{MoO}_{3}, \mathrm{ZnO}, \mathrm{ZnS}, \mathrm{TiO}_{2}, \ldots$ as dielectric and $\mathrm{Ag}, \mathrm{Cu}, \ldots$ as metal inside a dielectric/metal/dielectric three-layer structure. A Transfer Matrix Method (TMM) based numerical model is used to predict the optical behavior of the considered electrodes. ZnS/ $\mathrm{Ag} / \mathrm{TiO}_{\mathrm{x}}$ electrodes are manufactured by a vacuum electron beam evaporator on glass substrates, then characterized by UV-Visible spectrophotometer for obtaining transmittance and reflectance and by a four-point method for the measurement of sheet resistance. It is found that the simulation and experimental curves are quite similar. The transmittance is measured to be higher than $80 \%$ on a wide spectral band that can be tailored by the thickness of the upper dielectric material. The optical window $\Delta \lambda$, for $T>80 \%$, can be tuned in the 400-800 nm spectral band, according to the thickness of $\mathrm{TiO}_{\mathrm{x}}$ in the $25-50 \mathrm{~nm}$ range. This variation allows us to adapt our electrode to organic materials in order to optimize the performance of organic solar cells. The sheet resistance obtained is around to $7 \Omega / \mathrm{sq}$, which gives our electrodes the transparent and conductive character simultaneously. A typical parameter to compare the electrodes is the merit figure, which questions the average optical transmission $T_{\mathrm{av}}$ in the visible range and the sheet resistance $R_{\mathrm{sq}}$. By applying this figure to many manufactured electrodes, the obtained optimal structure of our TCEs is demonstrated to be $\mathrm{ZnS}(40 \mathrm{~nm}) / \mathrm{Ag}$ $(10 \mathrm{~nm}) / \mathrm{TiO}_{\mathrm{x}}(30 \mathrm{~nm})$.
\end{abstract}

Keywords: Multilayer / thin film / dielectric / metal / oxide / in-free transparent and conductive electrodes / organic solar cells / TMM numerical calculation

\section{Introduction}

The excessive use of fossil fuels causes the release of large amounts of $\mathrm{CO}_{2}$, leading to global warming of our planet. In order to limit the emission of greenhouse gases, fossil energy sources are being replaced by renewable sources such as sun, wind, etc. As a result, wind, hydraulic and solar energy are to be preferentially employed.

Solar energy based on the photovoltaic effect can be an efficient alternative. It is a well-adapted answer for the

\footnotetext{
* e-mail: philippe.torchio@univ-amu.fr
}

clean, inexhaustible production of electricity, and is a relatively well-distributed resource in the world, even if the average power received annually at the surface of the globe varies according to the regions. Furthermore, the size of photovoltaic systems can be adjusted and adapted to many applications.

The photovoltaic sector can be classified into three major categories: inorganic, organic and hybrid cells. The organic cells $[1,2]$ are essentially composed of an active layer sandwiched between two electrodes (cathode and anode). The photosensitive layer differs according to the nature of the organic material used, one of the two electrodes being metallic $(\mathrm{Al}, \mathrm{Ag}, \ldots)[3,4]$ while the other 
must be both transparent (allowing the passage of light in the heart of the cell) and conductive (to collect the electrical charges). The photovoltaic effect is based on the light conversion into electrical energy. This conversion involves a set of physical processes namely the absorption of the incident photons, exciton generation, exciton diffusion and dissociation, transport and collection of charges carriers.

Nowadays, ITO [5] remains the most widely used transparent conductive electrode (TCE) because of its excellent optical and electrical properties compared to other TCEs.

The current objective is then to keep these performances without employing indium, which becomes increasingly rare in nature. In addition, ITO cannot be used as flexible electrode given because of these poor mechanical properties. Among various alternatives, the three-layer dielectric/metal/dielectric structure $[6,7]$ can be seriously envisaged. Knowing that these structures are considered as a parallel connection of three resistors, and that the resistivity of the dielectric is much greater than that of the metal, so the total resistance of the entire stack is equivalent to that of the metal. From where we can admit that such tri-layers gain their character conductive of the presence of the metal.

$\mathrm{ZnS}$ has been used for many multilayer structures [8], associated with other dielectrics namely $\mathrm{MoO}_{3}[9,10]$, $\mathrm{WO}_{3}[11], \ldots$ or alternating multilayers with $\mathrm{Ag}(\mathrm{ZnS} /$ $\mathrm{Ag} / \mathrm{ZnS} / \mathrm{Ag} / \mathrm{ZnS}$ ) [12]. The $\mathrm{ZnS} / \mathrm{Ag} / \mathrm{TiO}_{2}$ three-layer was developed by Peres et al. [13] in 2016. He presented a study according to the thickness of $\mathrm{Ag}$ with a thickness of $\mathrm{TiO}_{\mathrm{x}}$ around 45 and $50 \mathrm{~nm}$. Our first objective consists in optimizing such multilayer with minimal thickness of $\mathrm{TiO}_{2}$ while keeping the performance of ITO. A second, rather important objective is to have the possibility of controlling the bandwidth (for transmission greater than $80 \%$ ) and its spectral position with respect to the absorption band of the organic material likely to be used in as an active layer in an organic solar cell.

\section{Numerical and experimental methods}

To model our structures, we use an algorithm based on the Transfer Matrix Method (TMM) [14,15], which assumes that the layers deposited are flat, massive and homogeneous; it also estimates that the light comes from a semiinfinite substrate in normal incidence and that the stack is surrounded by air [16]. This method [17,18] makes it possible to calculate the reflectance $(\mathrm{R})$, the transmittance (T) and the absorbance (A) of our structures after entering the complex optical constants (see Eq. (1)) of the materials used and the thicknesses of each layer as input data in the spectral [350,1500] based.

$$
\tilde{n}=n+i k .
$$

The electrodes are deposited on $\mathrm{VWR}^{\circledR}$ microscope slides $1 \mathrm{~mm}$-thick cut and cleaned. These substrates are placed in an Oerlikon Leybold Vacuum Univex 300 electron beam evaporator at normal incidence and $20 \mathrm{~cm}$ away from the crucibles containing the materials to be evaporated. The Ag thin film is deposited from $99.99 \%$ pure Ag at an average speed of $1 \mathrm{~nm} / \mathrm{s}$ and a vacuum around $4.10^{-5} \mathrm{mbar}$. The $\mathrm{TiO}_{\mathrm{x}}$ layer is deposited from a $99.995 \% \mathrm{TiO}_{2}$ pure material at a rate of $0.2 \mathrm{~nm} / \mathrm{s}$ and a vacuum around $9 \cdot 10^{-5}$ mbar. No oxygen is added during the deposition process, involving a non-stoichiometry $\mathrm{TiO}_{\mathrm{x}}$. That of $\mathrm{ZnS}$ is deposited from a $99.999 \%$ pure powder of Zinc Sulfide at a speed close to $0.5 \mathrm{~nm} / \mathrm{s}$ and a vacuum around $5.10^{-5} \mathrm{mbar}$. The thicknesses are controlled via a quartz crystal oscillator monitor placed near the substrate during deposition and confirmed posteriori by a mechanical profilometer. Quartz does not give an exact value of the thickness, which makes the repetition caused by a thickness measurement error of the order of $\pm 5 \mathrm{~nm}$ for the oxides and $\pm 1 \mathrm{~nm}$ for the metals. The samples are optically characterized by spectrophotometry, including an integrating sphere. The absorption spectra $(\mathrm{A}=1-R-T)$ are deduced from the $R$ and $T$ measurements.

The electrical measurements are carried out by the 4-point method which consists of applying a current intensity $I$ and of measuring the voltage difference $\Delta V$. The sheet resistance can be then calculated according to the following equation (2):

$$
R_{\mathrm{sq}}=4.53 \times \frac{\Delta V}{I} .
$$

\section{Results and discussion}

To determine the input parameters of our modelling algorithm, i.e. the complex optical constants of each material, we use data previously obtained by ellipsometry spectroscopy on monolayers of $\mathrm{ZnS}$ and $\mathrm{TiO}_{\mathrm{x}}$. From a Tauc-Lorentz model, it was possible to adjust the measured ellipsometric values tan $(\psi)$ and $\cos (\Delta)$ of $\mathrm{ZnS}$ and $\mathrm{TiO}_{\mathrm{x}}$ [14]. Optical constants of bulk Ag are coming from the literature [19].

The simulation of the transmission as a function of the thicknesses of the three layers for the Glass/ZnS/Ag/ $/ \mathrm{TiO}_{\mathrm{x}}$ structure is investigated. For optimum conductivity, a thickness of $10 \mathrm{~nm} \mathrm{Ag}$ was previously set [20,21]. In the thickness ranges $20-50 \mathrm{~nm}$ for $\mathrm{ZnS}$ and $0-50 \mathrm{~nm}$ for $\mathrm{TiO}_{\mathrm{x}}$, mapping of the calculated transmission can be drawn and reported in Figure 1.

For a transmission greater than $80 \%$, it can be predicted from Figure 1 that the optimal thicknesses of $\mathrm{ZnS}$ and $\mathrm{TiO}_{\mathrm{x}}$ are ranging in $20-50 \mathrm{~nm}$. The transmittance is also able to exceed $85 \%$ in the range $27-48 \mathrm{~nm}$ for $\mathrm{TiO}_{\mathrm{x}}$ and $22-50 \mathrm{~nm}$ for $\mathrm{ZnS}$. The optimal thicknesses of the two peripheral layers of our structure can be centered around $40 \mathrm{~nm}$ for $\mathrm{ZnS}$ and $35 \mathrm{~nm}$ for $\mathrm{TiO}_{\mathrm{x}}$; in this configuration, the calculated transmittance, reflectance and absorptance curves can be plotted versus wavelength in the 400-1500 nm spectral band for the $\mathrm{ZnS}(40 \mathrm{~nm}) / \mathrm{Ag}$ $(10 \mathrm{~nm}) / \mathrm{TiO}_{\mathrm{x}}(35 \mathrm{~nm})$ electrode (see dashed lines in Fig. 2). It is then clearly observed a wide transmittance bandwidth (for while $T$ is $>80 \%$ ) in the $400-800 \mathrm{~nm}$ 


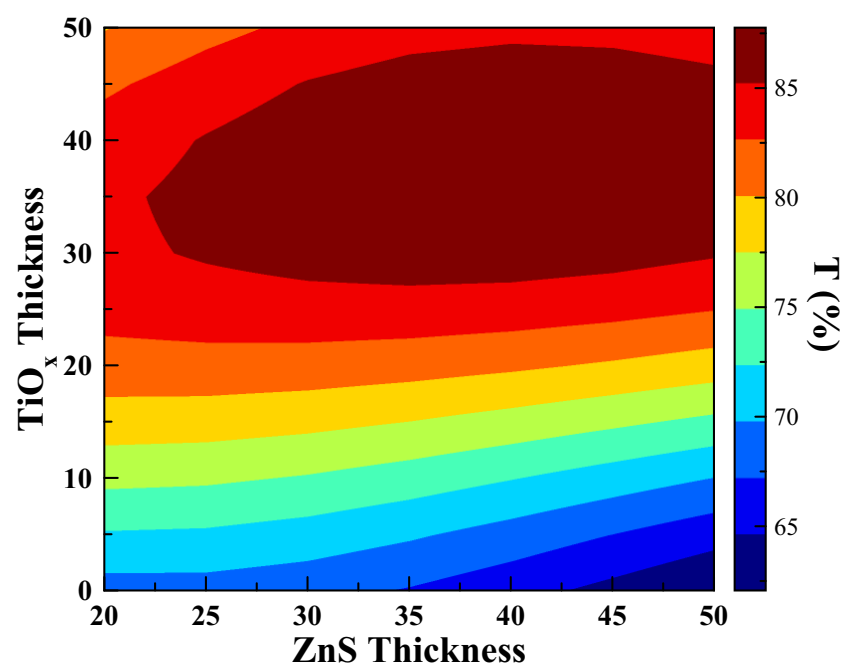

Fig. 1. Mapping of the transmittance $(\mathrm{T})$ versus $\mathrm{ZnS}$ and $\mathrm{TiO}_{\mathrm{x}}$ thicknesses of $\mathrm{ZnS} / \mathrm{Ag} / \mathrm{TiO}_{\mathrm{x}}$ electrodes with a fixed value of 10 nm-thick Ag.

range.After manufacturing of the electrodes around the optimal thicknesses values, we are able to compare the experimental optical properties measurements (transmission, reflection and absorption) to those obtained by simulation (Fig. 2). The measured curves are in full line, while the simulated curves are in dashed lines. Results are globally in good agreement for Glass/ZnS $(40 \mathrm{~nm}) /$ $\mathrm{Ag}(10 \mathrm{~nm}) / \mathrm{TiO}_{\mathrm{x}}(35 \mathrm{~nm})$ electrode. However a slight difference can be observed towards the UV spectral part, probably due to the morphology of $\mathrm{Ag}$, which is probably not totally homogeneous but can present some nanoislands for the very thin thickness of $10 \mathrm{~nm}$. This can result in enhanced absorption due to plasmonic resonances, involving a decreased transmittance for the experimental electrodes compared to the theoretical ones (heterogeneities in $\mathrm{Ag}$ morphology are not taken into consideration by simulation).

The experimental optical and electrical results obtained from various fabricated electrodes are summarized in Table 1 . The thickness of silver is fixed to $10 \mathrm{~nm}$, while the $\mathrm{ZnS}$ thickness is equal to $35 \mathrm{~nm}$ and $\mathrm{TiO}_{\mathrm{x}}$ varies between 25 and $50 \mathrm{~nm}$ (with a step of $5 \mathrm{~nm}$ ). This latter value is varied in order to have benefit of the ability of the upper layer to tune the transmittance frequency band (due to the interferential effect occurring in the whole multilayer). All electrodes have a low sheet resistance (less than $8 \Omega / \mathrm{sq}$ ) which values varying between 7.4 and $7.8 \Omega /$ sq. The $\mathrm{ZnS}$ $(35 \mathrm{~nm}) / \mathrm{Ag}(10 \mathrm{~nm}) / \mathrm{TiO}_{\mathrm{x}}(30 \mathrm{~nm})$ electrode appears to the most conductive one $(7.43 \Omega / \mathrm{sq})$.

Figure 3 shows the transmission of $\mathrm{ZnS}(35 \mathrm{~nm}) / \mathrm{Ag}$ $(10 \mathrm{~nm}) / \mathrm{TiO}_{\mathrm{x}}(y \mathrm{~nm})$ structures for different thicknesses $y$ of $\mathrm{TiO}_{\mathrm{x}}$. Our structure has a large optical transmittance window (for $T>80 \%$ ), and it approaches that of the ITO. The width of this optical window can also be controlled by the thickness of the y upper layer of our structure. This is confirmed by the inset curve inside Figure 3, which shows the variation of the width of the optical band as well as its

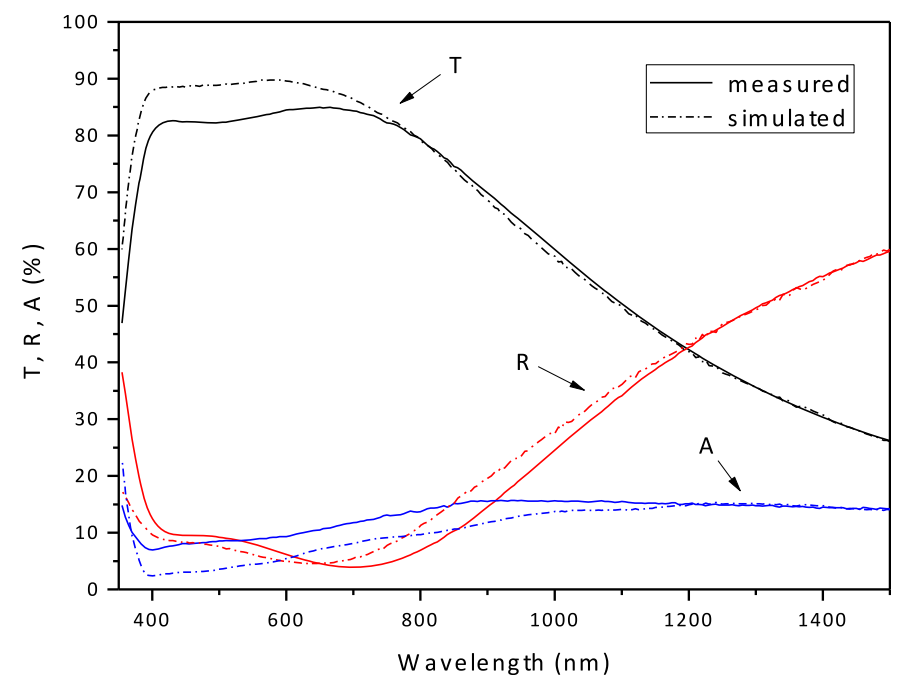

Fig. 2. Simulated and measured transmittance $(\mathrm{T})$, reflectance (R) and absorptance (A) for Glass/ZnS $(40 \mathrm{~nm}) / \mathrm{Ag}(10 \mathrm{~nm}) /$ $\mathrm{TiO}_{\mathrm{x}}(35 \mathrm{~nm})$.

Table 1. Optical and electrical properties of various manufactured Glass/ZnS/Ag/ $\mathrm{TiO}_{\mathrm{x}}$ electrodes.

\begin{tabular}{|c|c|c|c|c|c|}
\hline Electrodes & $\begin{array}{l}\mathrm{R}_{\mathrm{sq}} \\
(\Omega / \mathrm{sq})\end{array}$ & $\begin{array}{l}T_{\max } \\
(\%)\end{array}$ & $\begin{array}{l}\lambda_{\max } \\
(\mathrm{nm})\end{array}$ & $\begin{array}{l}\mathrm{D} \lambda_{T>80 \%} \\
(\mathrm{~nm})\end{array}$ & $\begin{array}{l}\text { Figure of } \\
\text { merit } \\
\left(10^{-3} \Omega^{-1}\right)\end{array}$ \\
\hline $\begin{array}{l}\mathrm{ZAT}(35 / 10 / \\
25) \mathrm{nm}\end{array}$ & 7.6 & 83.27 & 575 & $375-695$ & 20 \\
\hline $\begin{array}{l}\text { ZAT }(35 / 10 / \\
30) \mathrm{nm}\end{array}$ & 7.43 & 85.19 & 600 & $395-720$ & 23 \\
\hline $\begin{array}{l}\mathrm{ZAT}(35 / 10 / \\
35) \mathrm{nm}\end{array}$ & 7.65 & 84.95 & 650 & $400-785$ & 21 \\
\hline $\begin{array}{l}\mathrm{ZAT}(35 / 10 / \\
45) \mathrm{nm}\end{array}$ & 7.6 & 83.71 & 725 & $595-830$ & 10 \\
\hline $\begin{array}{l}\mathrm{ZAT}(35 / 10 / \\
50) \mathrm{nm}\end{array}$ & 7.8 & 80.84 & 765 & $715-805$ & 6.9 \\
\hline
\end{tabular}

spectral position. Indeed, the optical window widens by decreasing the thickness of $\mathrm{TiO}_{\mathrm{x}}$, and turns towards the infrared for thicknesses greater than $45 \mathrm{~nm}$. The spectral range is $375-695 \mathrm{~nm}$ for $y=25 \mathrm{~nm} ; 395-720 \mathrm{~nm}$ for $y=30 \mathrm{~nm} ; \quad 400-786 \mathrm{~nm}$ for $y=35 \mathrm{~nm} ; 595-830 \mathrm{~nm}$ for $y=45 \mathrm{~nm}$; and $715-805 \mathrm{~nm}$ for $y=50 \mathrm{~nm}$.

Figure 4 shows the displacement of $\lambda_{\max }$ with the increase of $\mathrm{TiO}_{\mathrm{x}}$ thickness, from $575 \mathrm{~nm}$ for $25 \mathrm{~nm}$-thick $\mathrm{TiO}_{\mathrm{x}}$ to $765 \mathrm{~nm}$ for $50 \mathrm{~nm}$-thick $\mathrm{TiO}_{\mathrm{x}}$. We can notice from the same figure that the value of $T_{\max }$ also depends on the thickness of the upper layer of our structure. Indeed, for small thicknesses, $T_{\max }$ increases up to $85.19 \%$ for $30 \mathrm{~nm}$ thick $\mathrm{TiO}_{\mathrm{x}}$, then decreases for thicknesses greater than $30 \mathrm{~nm}$ until reaching a value of $80.84 \%$ for $50 \mathrm{~nm}$-thick $\mathrm{TiO}_{\mathrm{x}}$. 


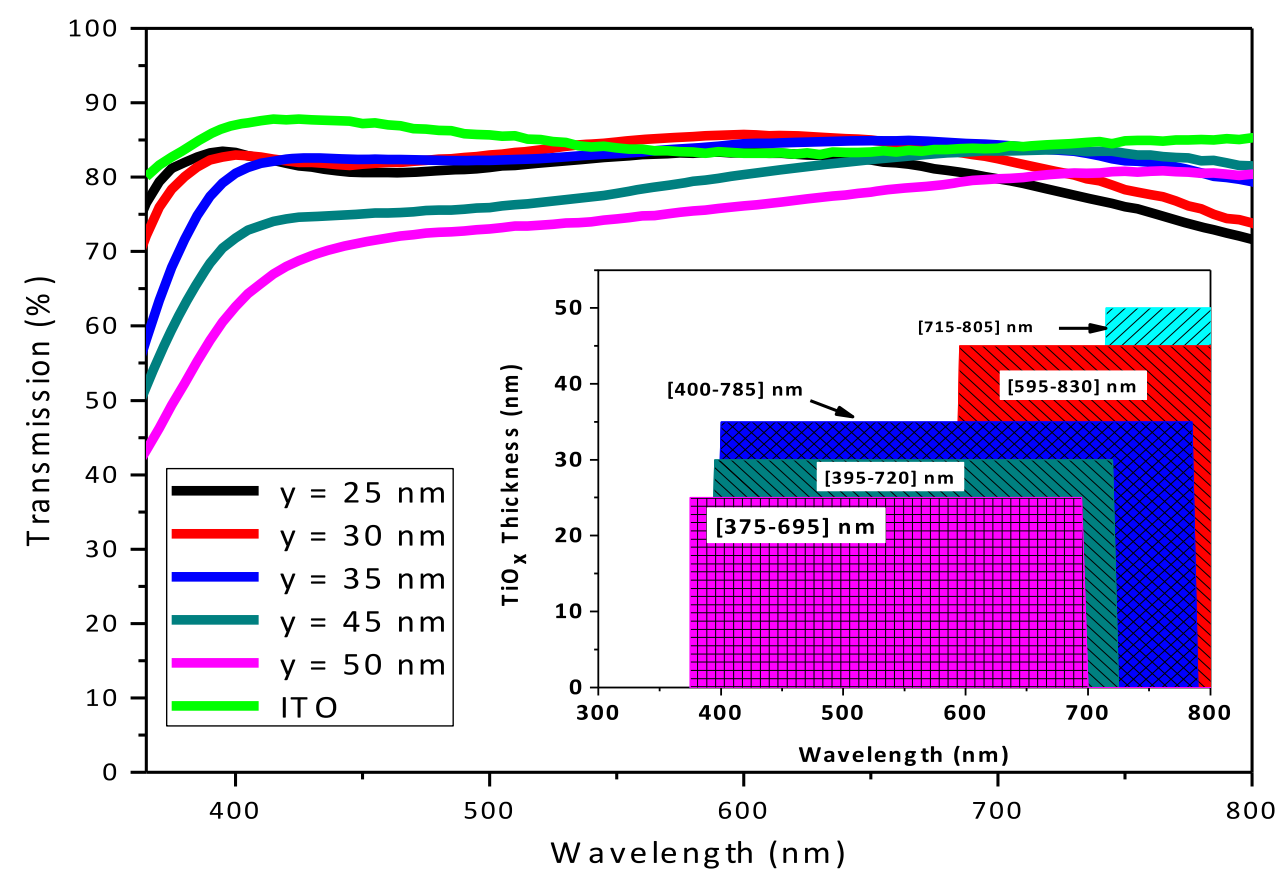

Fig. 3. Variation of the transmittance as a function of wavelength for the $\mathrm{ZnS}(35 \mathrm{~nm}) / \mathrm{Ag}(10 \mathrm{~nm}) / \mathrm{TiO}_{\mathrm{x}}(y \mathrm{~nm})$ structure.

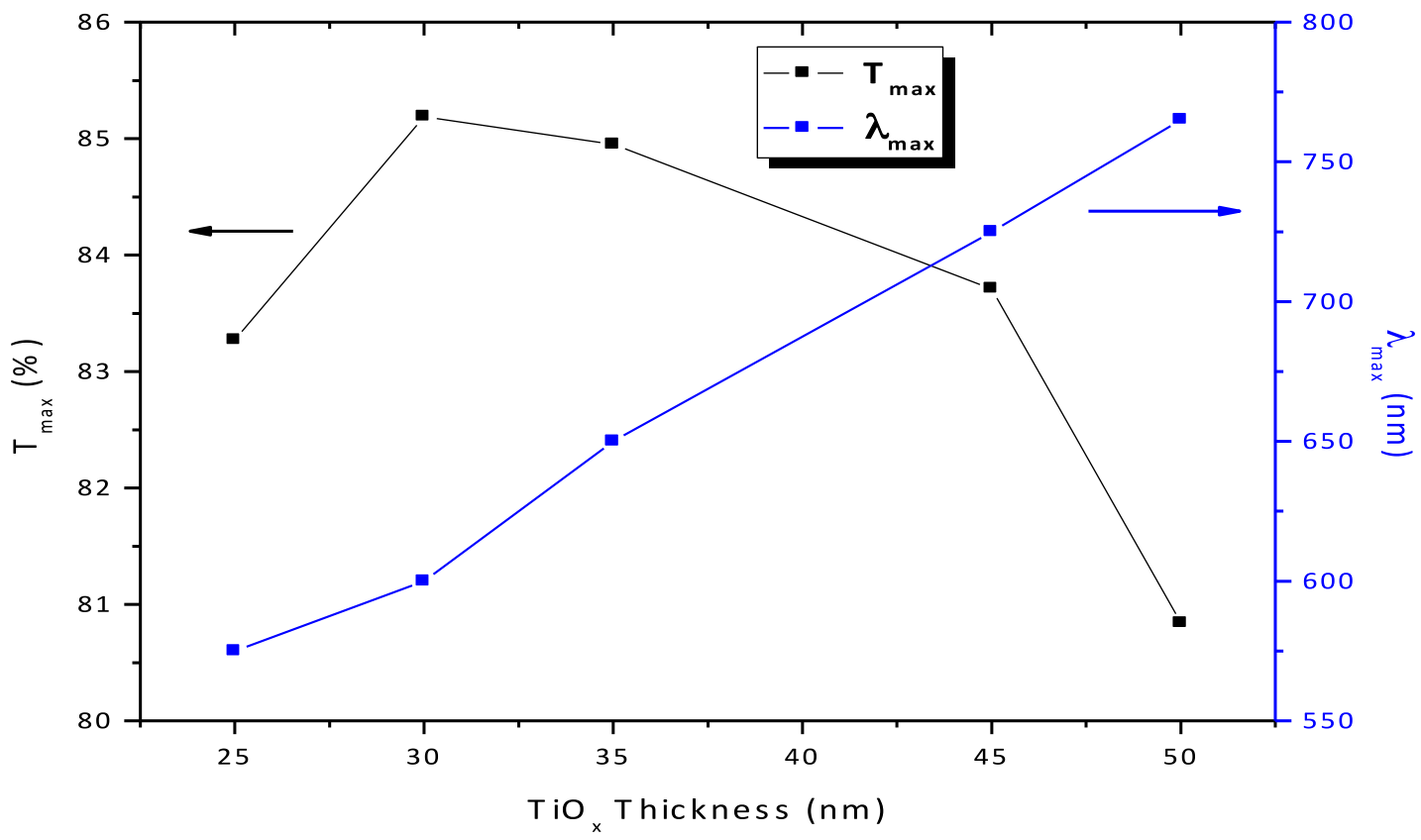

Fig. 4. Variation of $T_{\max }$ and $\lambda_{\max }$ as a function of $\mathrm{TiO}_{\mathrm{x}}$ thickness for the $\mathrm{ZnS}(35 \mathrm{~nm}) / \mathrm{Ag}(10 \mathrm{~nm}) / \mathrm{TiO}$ ( $(y \mathrm{~nm})$ structure.

The optical window $\left(\Delta \lambda_{T>80 \%}\right)$ for which the transmission exceeds $80 \%$ is also presented (Tab. 1). This transmission window can be tailored between 375 and $830 \mathrm{~nm}$, and can therefore be adapted to the useful absorption band of the photoactive material employed in the organic solar cell
(Fig. 5). The absorption band of an organic solar cell is mainly dependant of the electron donor material, and is generally included in this previous cited range.

As shown in Figure 5, different organic materials used as an active layer in organic solar cells are presented. Two 


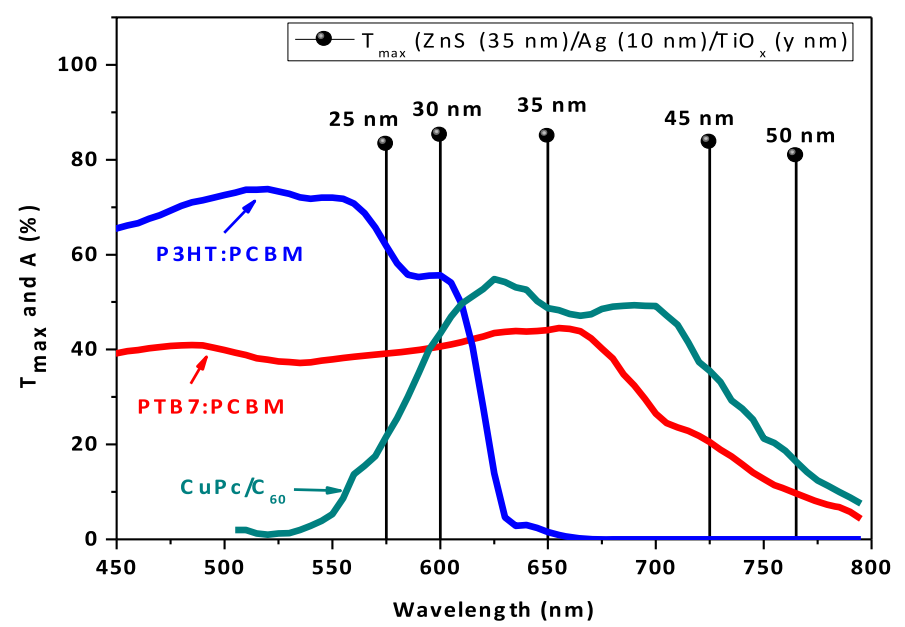

Fig. 5. Absorption $(A)$ of some organic materials (P3HT:PCBM, PTB7:PCBM, CuPc/ $\left.\mathrm{C}_{60}\right)$ and maximal transmittance $T_{\max }$ of $\mathrm{ZnS}(35 \mathrm{~nm}) / \mathrm{Ag}(10 \mathrm{~nm}) / \mathrm{TiO}_{\mathrm{x}}(y \mathrm{~nm})$ as a function of $y$ thickness which is equal to $25-30-35-45-50 \mathrm{~nm}$.

typical interpenetrated networks based on donor:acceptor bulk heterojunction (P3HT:PCBM and PTB7:PCBM) and one binary planar heterojunction $\left(\mathrm{CuPc} / \mathrm{C}_{60}\right)$ made of small molecules. They present 3 different absorption bands. We also report in this figure the maximal transmission of our electrodes (on the y-axis) and their spectral position (on the x-axis), which depends on the thickness of $\mathrm{TiO}_{\mathrm{x}}$ (equal to $25-30-35-45-50 \mathrm{~nm}$ ). Note that we can adapt to each organic material its proper electrode. The $25 \mathrm{~nm}$-thick- $\mathrm{TiO}_{\mathrm{x}}$ electrode can be associated with P3HT:PCBM, that of 30 and $35 \mathrm{~nm}$-thick- $\mathrm{TiO}_{\mathrm{x}}$ can be associated with PTB7:PCBM and that of 45 and $50 \mathrm{~nm}-$ thick- $\mathrm{TiO}_{\mathrm{x}}$ can be associated with $\mathrm{CuPc} / \mathrm{C}_{60}$.

To classify our electrodes and to detect the most efficient ones, we can use the typical figure of merit $\Phi$ that is related to the optical and electrical properties of the sample by the following expression [22]:

$$
\Phi=\frac{T_{\mathrm{av}}^{10}}{R_{\mathrm{sq}}}
$$

with $T_{\mathrm{av}}^{10}$ the average transmission in the visible range and $R_{\mathrm{sq}}$ the sheet resistance.

The different values of $F$ are also given in Table 1; they are obtained from the average transmission in the visible range $400-800 \mathrm{~nm}$. The $\mathrm{ZnS}(40 \mathrm{~nm}) / \mathrm{Ag}(10 \mathrm{~nm}) / \mathrm{TiO}_{\mathrm{x}}$ $(30 \mathrm{~nm})$ TCE presents the best $F$ value $\left(23.10^{-3} \mathrm{~W}^{-1}\right)$. This high-level value is comparable to those of the current stateof-the-art [14-23]. Figure 6 shows the variation of the merit figure and of the sheet resistance as a function of $\mathrm{TiO}_{\mathrm{x}}$ thickness. The merit figure decreases by increasing the thickness of $\mathrm{TiO}_{\mathrm{x}}$ while the sheet resistance remains practically steady.
For photovoltaic applications, it is also essential to have a suitable work function of the considered electrodes. The commercial ITO has a work function varied from 4.4 to $4.8 \mathrm{eV}$ [24]. We have previously studied and measured the work function of tri-layer electrodes made by electron beam deposition by means of Kelvin Probe Force Microscopy. By using $\mathrm{Ag}$ as metal and $\mathrm{SnO}_{\mathrm{x}}, \mathrm{TiO}_{\mathrm{x}}$ or $\mathrm{ZnS}$ as dielectric in the multilayer electrodes, we obtained for example the work function values of $4.83,4.75$ and $4.48 \mathrm{eV}$ for $\mathrm{TiO}_{\mathrm{x}} /$ $\mathrm{Ag} / \mathrm{TiO}_{\mathbf{x}}, \mathrm{SnO}_{\mathbf{x}} / \mathrm{Ag} / \mathrm{SnO}_{\mathbf{x}}$ and $\mathrm{ZnS} / \mathrm{Ag} / \mathrm{ZnS}$ respectively [25]. Because of similarities in the design of the TCE and in the materials properties, we can estimate that the values of the $\mathrm{ZnS} / \mathrm{Ag} / \mathrm{TiO}_{\mathrm{x}}$ will remain around these values, which are close to that of the ITO and allow keeping equivalent charge transfer properties.

The opto-electrical performances of our electrodes are at the-state-of-the-art of this ETC field [26]. With a fairly large merit figure comparable to literature values [23,27-29], such transparent, conductive three-layer electrodes are good candidates for use as indium-free electrode in organic solar cells.

\section{Conclusion}

Glass $/ \mathrm{ZnS} / \mathrm{Ag} / \mathrm{TiO}_{\mathrm{x}}$ structures are optically and electrically optimized to obtain the best compromise between high transmittance and low sheet resistance. Such ETC are manufactured by e-beam evaporation. Their measured optical properties are in good agreement with the predictive optical simulation. A transmittance level higher than $80 \%$ is obtained on a wide spectral range while a sheet resistance of the order of $7.6 \Omega / \mathrm{sq}$ is measured. The optical transmittance bandwidth can be tuned by the thickness of the $\mathrm{TiO}_{\mathrm{x}}$ upper layer in the $400-800 \mathrm{~nm}$ absorption spectral band of the most electron donors involved in organic solar cells. An optimal ZnS (40 nm)/Ag (10 nm)/ $\mathrm{TiO}_{\mathrm{x}}(30 \mathrm{~nm})$ electrode, with a figure of merit of $23.10^{-3} \Omega^{-1}$, is realized. Such ETCs are at the-state-ofthe-art of the domain, and could be employed for producing Indium-free organic solar cells.

The authors acknowledge funding from the European Community ERANETMED ENERG-11-196: Project NInFFE "New Indium Free Flexible Electrode" (H2020 Program).

\section{Author contribution statement}

As $\mathrm{PhD}$ student, M.A.C. did the numerical and experimental work, and wrote the first version of the paper. A.L. contributed to the experimental part. D.B. supervised the experiments and contributed to the interpretation of the results. As co-director of the thesis of M.A.C., S.T. approved the presented results. Ph.T. is the co-director of the thesis of M.A.C.; he supervised the work and the data analysis, contributed to the interpretation of the results, and coordinated the manuscript preparation and submission. 


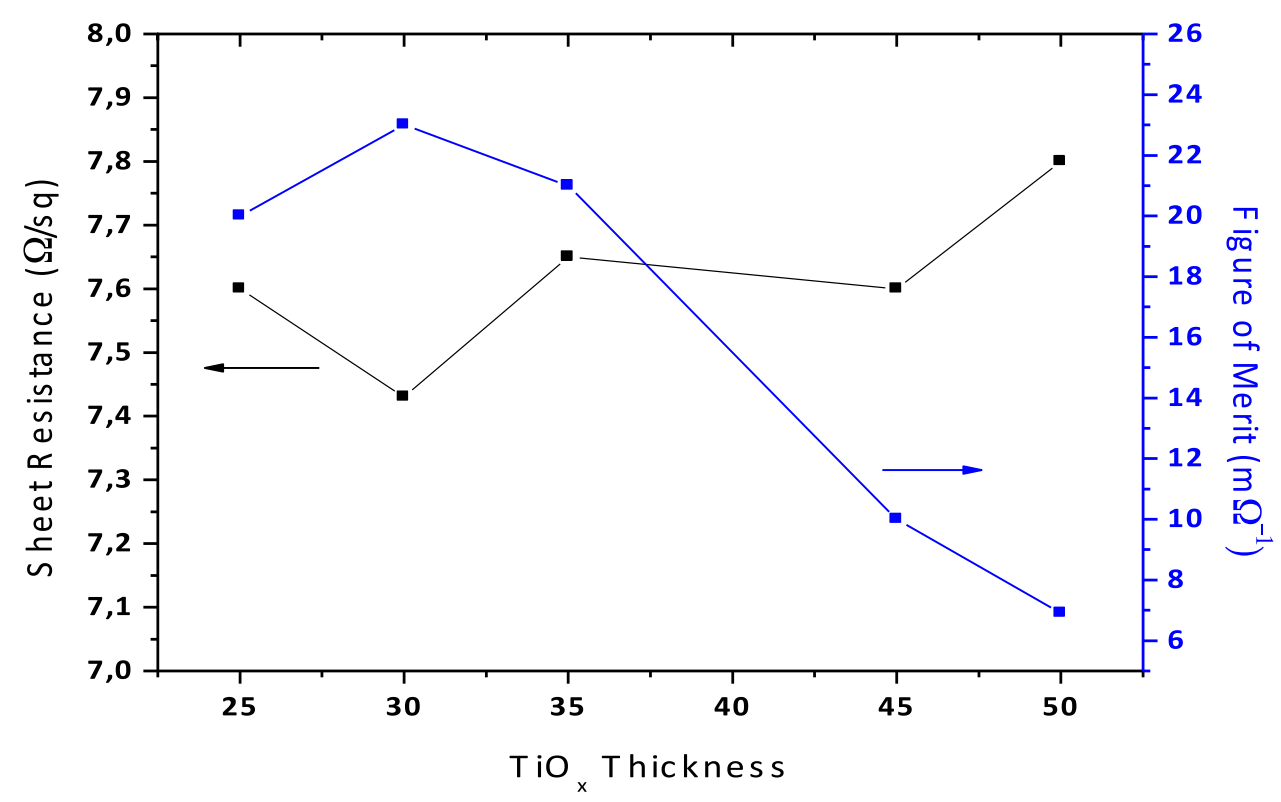

Fig. 6. Sheet resistance (black curve-scale on the left) and merit figure (blue curve-scale on the right) for Glass $/ \mathrm{ZnS}(35 \mathrm{~nm}) / \mathrm{Ag}$ $(10 \mathrm{~nm}) / \mathrm{TiO}_{\mathrm{x}}(25-50 \mathrm{~nm})$ ETCs.

\section{References}

1. R.F. Service, Solar energy. Outlook brightens for plastic solar cells, Science 332, $293(2011)$

2. M.A. Green, K. Emery, Y. Hishikawa, W. Warta, E.D. Dunlop, Solar cell efficiency tables (version 41), Prog. Photovolt.: Res. Appl. 21, 1 (2013)

3. C. Guillén, J. Herrero, ITO/metal/ITO multilayer structures based on $\mathrm{Ag}$ and $\mathrm{Cu}$ metal films for high-performance transparent electrodes, Sol. Energy Mater. Sol. Cells 92, 938 (2008)

4. M. Chakaroun, B. Lucas, B. Ratier, M. Aldissi, ITO/Au/ITO multilayer electrodes for $\mathrm{CuPc} / \mathrm{C}_{60}$ solar cells, Energy Proced. 31, 102 (2012)

5. K. Ellmer, Past achievements and future challenges in the development of optically transparent electrodes, Nat. Photon. 6, 808 (2012)

6. M. Chakaroun, B. Lucas, B. Ratier, C. Defranoux, J.P. Piel, M. Aldissi, High quality transparent conductive electrodes in organic photovoltaic devices, Thin Solid Films 518, 1250 (2009)

7. Y.-S. Park, H.-K. Park, J.-A. Jeong, H.-K. Kim, K.-H. Choi, S.-I. Na, D.-Y. Kim, Comparative investigation of transparent ITO $/ \mathrm{Ag} / \mathrm{ITO}$ and ITO $/ \mathrm{Cu} /$ ITO electrodes grown by dual-target DC sputtering for organic photovoltaics, J. Electrochem. Soc. 156, 588 (2009)

8. Y. Mouchaal, G. Louarn, A. Khelil, M. Morsli, N. Stephant, A. Bou, T. Abachi, L. Cattin, M. Makha, P. Torchio, J.C. Bernède, Broadening of the transmission range of dielectric/ metal multilayer structures by using different metals, Vacuum 111, 32 (2015)

9. H. Kermani, H.R. Fallah, M. Hajimahmoodzadeh, Design and fabrication of nanometric $\mathrm{ZnS} / \mathrm{Ag} / \mathrm{MoO}_{3}$ transparent conductive electrode and investigating the effect of annealing process on its characteristics, Physica E 47, 303 (2013)
10. Y.C. Han, M.S. Lim, J.H. Park, K.C. Choi, ITO-free flexible organic light-emitting diode using $\mathrm{ZnS} / \mathrm{Ag} / \mathrm{MoO}_{3}$ anode incorporating a quasi-perfect $\mathrm{Ag}$ thin film, Org. Electron. 14, 3437 (2013)

11. H. Cho, C. Yun, J.-W. Park, S. Yoo, Highly flexible organic light-emitting diodes based on $\mathrm{ZnS} / \mathrm{Ag} / \mathrm{WO}_{3}$ multilayer transparent electrodes, Org. Electron. 10, 1163 (2009)

12. H. Kermani, H.R. Fallah, M. Hajimahmoodzadeh, N. Basri, Design and construction of an improved nanometric $\mathrm{ZnS}$ / $\mathrm{Ag} / \mathrm{ZnS} / \mathrm{Ag} / \mathrm{ZnS}$ transparent conductive electrode and investigating the effect of annealing on its characteristics, Thin Solid Films 539, 222 (2013)

13. L. Peres, A. Bou, D. Barakel, P. Torchio, ZnS $|\mathrm{Ag}| \mathrm{TiO}_{2}$ multilayer electrodes with broadband transparency for thin film solar cells, RSC Adv. 6, 461057 (2016)

14. A. Bou, P. Torchio, D. Barakel, P.-Y. Thoulon, M. Ricci, Numerical and experimental investigation of transparent and conductive $\mathrm{TiO}_{\mathrm{x}} / \mathrm{Ag} / \mathrm{TiO}_{\mathrm{x}}$ electrode, Thin Solid Films 617, 86 (2016)

15. S.M. Durrani, E. Khawaja, A. Al-Shukri, M. Al-Kuhaili, Dielectric/Ag/dielectric coated energy-efficient glass windows for warm climates, Energy Build. 36, 891 (2004)

16. F. Abelès, La détermination de l'indice et de l'épaisseur des couches minces transparentes, J. Phys. Radium 11, 310 (1950)

17. A. Bou, P. Torchio, D. Barakel, F. Thierry, P.-Y. Thoulon, M. Ricci, Indium tin oxide-free transparent and conductive electrode based on $\mathrm{SnO}_{\mathrm{x}}|\mathrm{Ag}| \mathrm{SnO}_{\mathrm{x}}$ for organic solar cells, in Oxide-based Materials and Devices V, Proc. SPIE 8987 (SPIE, 2014), p. 898706

18. S.A. Dyakov, V.A. Tolmachev, E.V. Astrova, S.G. Tikhodeev, V.Y. Timoshenko, T.S. Perova, in: K.A. Valiev, A.A. Orlikovsky (Eds.), in International Conference on Micro-Nano-Electronics 2009 (SPIE, Zvenigorod, 2009), p. 75210G

19. E. Palik, Handbook of optical constants of solids (Elsevier I, Washington, 1997) 
20. Z. Zhao, T.L. Alford, The optimal $\mathrm{TiO}_{2} / \mathrm{Ag} / \mathrm{TiO}_{2}$ electrode for organic solar cell application with high device-specific Haake figure of merit, Sol. Energy Mater. Sol. Cells 157, 599 (2016)

21. A. Bou, P. Torchio, S. Vedraine, D. Barakel, B. Lucas, J.-C. Bernède, P.-Y. Thoulon, M. Ricci, Numerical optimization of multilayer electrodes without indium for use in organic solar cells, Sol. Energy Mater. Sol. Cells 125, 310 (2014)

22. G. Haacke, New figure of merit for transparent conductors, J. Appl. Phys. 47, 4086 (1976)

23. H. Zhou, J. Xie, M. Mai, J. Wang, X. Shen, S. Wang, L. Zhang, K. Kisslinger, H.-Q. Wang, J. Zhang, Y. Li, J. Deng, S. Ke, X. Zeng, A high-quality AZO/Au/AZO sandwich film with ultra-low optical loss and resistivity for transparent flexible electrodes, ACS Appl. Mater. Interfaces 10, 16160 (2018)

24. Y. Park, V. Choong, B.R. Hsieh, C.W. Tang, Work function of indium tin oxide transparent conductor measured by photoelectron spectroscopy, Appl. Phys. Lett. 68, 2699 (1996)
25. L. Peres, A. Bou, C. Cornille, D. Barakel, P. Torchio, Work function measurement of multilayer electrodes using Kelvin Probe Force Microscopy, J. Phys. D: Appl. Phys. 50, 13LT01 (2017)

26. Z. Zhao, T.L. Alford, The optimal $\mathrm{TiO}_{2} / \mathrm{Ag} / \mathrm{TiO}_{2}$ electrode for organic solar cell application with high device-specific Haacke figure of merit, Sol. Energy Mater. Sol. Cells 157, 599 (2016)

27. M. Wang, A. Barnabé, Y. Thimont, J. Wang, Y. He, Q. Liu, X. Zhong, G. Dong, J. Yang, X. Diao, Optimized properties of innovative electrochromic device using ITO $/ \mathrm{Ag} / \mathrm{ITO}$ electrodes, Electrochim. Acta 301, 200 (2019)

28. D. Das, L. Karmakar, Further optimization of ITO films at the melting point of Sn and configuration of Ohmic contact at the c-Si/ITO interface, Appl. Surf. Sci. (2019). DOI: 10.1016/ j.apsusc.2019.03.074

29. B. Sarma, B.K. Sarma, Role of residual stress and texture of $\mathrm{ZnO}$ nanocrystals on electro-optical properties of $\mathrm{ZnO} / \mathrm{Ag} /$ $\mathrm{ZnO}$ multilayer transparent conductors, J. Alloy. Compd. 734, 210 (2018)

Cite this article as: Mohamed Ahmed Cherif, Amina Labiod, Damien Barakel, Saad Touihri, Philippe Torchio, Tailored ZnS/ $\mathrm{Ag} / \mathrm{TiO}_{\mathrm{x}}$ transparent and conductive electrode for organic solar cells, EPJ Photovoltaics 10, 2 (2019) 